\title{
Lactoferrin-loaded Alginate Microparticles to Target Clostridioides difficile infection
}

Shwana Braim, ${ }^{\mathrm{a}}$ Klaudyna Śpiewak ${ }^{\mathrm{b}}$, Malgorzata Brindell, ${ }^{\mathrm{b}}$ Daniela Heeg, ${ }^{\mathrm{c}}$ Cameron Alexander ${ }^{a}$, and Tanya Monaghan ${ }^{*}$

a School of Pharmacy, The University of Nottingham, University Park, Nottingham, UK, NG7 2RD,E-mail: Cameron.Alexander@nottingham.ac.uk,

bJagiellonian University in Kraków, Faculty of Chemistry, Department of Inorganic Chemistry, Gronostajowa St. 2, 30-387 Kraków, Poland

${ }^{c}$ CHAIN Biotechnology Ltd, Nottingham, UK

${ }^{d}$ NIHR Nottingham Digestive Diseases Biomedical Research Centre, Nottingham University Hospitals NHS Trust and the University of Nottingham, Nottingham, UK and Nottingham Digestive Diseases Centre, School of Medicine, University of Nottingham, Nottingham, UK, NG7 2UH, Email: Tanya.Monaghan@nottingham.ac.uk

Corresponding author(s)*: Dr Tanya Monaghan

Primary corresponding author:

Dr Tanya Monaghan

NIHR Nottingham Biomedical Research Centre, Nottingham University Hospitals NHS Trust and the University of Nottingham, Nottingham, UK and Nottingham Digestive Diseases

Centre, School of Medicine, University of Nottingham, Nottingham NG7 2UH, UK.

Tel: $01159249924 \times 60589$

Tanya.Monaghan@nottingham.ac.uk 


\begin{abstract}
Some forms of bovine lactoferrin (bLf) are effective in delaying Clostridioides difficile growth and preventing toxin production. However, therapeutic use of bLf may be limited by protein stability issues. The objective of this study was to prepare and evaluate colon-targeted, $\mathrm{pH}$ triggered alginate microparticles loaded with bioactive bLf and to evaluate their anti- $C$.

difficile defence properties in vitro. Different forms of metal-bound bLf were encapsulated in alginate microparticles using an emulsification/internal gelation method. The microparticles were coated with chitosan to control protein release. In vitro drug release studies were conducted in $\mathrm{pH}$-simulated gastrointestinal conditions to investigate the release kinetics of encapsulated protein. No significant release of metal-bound bLf was observed at acidic $\mathrm{pH}$; however, on reaching simulated colonic $\mathrm{pH}$, most of the encapsulated lactoferrin was released. The application of bLf $(5 \mathrm{mg} / \mathrm{mL})$ delivered from alginate microparticles to human intestinal epithelial cells (hIECs) significantly reduced the cytotoxic effects of toxins $A$ and $B$ as well as bacterial supernatant on Caco-2 and Vero cells, respectively. These results are the first to suggest that alginate-bLf microparticles show protective effects against $C$. difficile toxin-mediated epithelial damage and impairment of barrier function in hIECs. The future potential of lactoferrin-loaded alginate microparticles against $C$. difficile deserves further study.
\end{abstract}

\title{
KEYWORDS
}

Lactoferrin, alginate microparticles, Clostridioides difficile, targeted drug delivery, gastrointestinal tract. 


\section{Introduction}

Successful oral delivery of peptides and proteins requires protection of the macromolecules from loss of bioactivity or degradation in the gastrointestinal tract. ${ }^{1,2}$ Targeted delivery of drugs and proteins into the colon is important for local treatment of a range of diseases. ${ }^{3}$ Different approaches have been developed for colon specific drug delivery including coating with $\mathrm{pH}$ - responsive polymers, preparing timed-release formula, and colonic bacteria responsive degradation of formula. ${ }^{4,5}$ Among the aforementioned strategies, the use of $\mathrm{pH}$ responsive polymers holds great promise. Various $\mathrm{pH}$-triggered polymer polysaccharides have been studied for this purpose. ${ }^{6}$

Alginate microparticles possess some unique characteristics that enable these particles to be used for the controlled delivery of proteins. For example, alginate microparticles have excellent biodegradability, biocompatibility, and $\mathrm{pH}$-responsive swelling behaviour. As a consequence, alginates are used in a number of pharmaceutical applications, but alginate particles in particular are used to control release of oral delivery of drugs and proteins. ${ }^{7,8,9,10,11,12,13}$ Alginate-derived polymers can easily be formulated into controllable diameter microparticles with appropriate size distributions for ingestion $(\sim 100 \mu \mathrm{m}))^{7}$ These particles can be prepared by various techniques such as microfluidic fabrication, ${ }^{14,15,16,17}$ air atomization, ${ }^{18,19,20}$ emulsification/internal gelation, ${ }^{21}$ complexation with counterion polymers, ${ }^{22}$ spray-drying, ${ }^{23}$ impinging aerosols, ${ }^{24,25}$ and inkjet/drying processes. ${ }^{26}$ Among these techniques, emulsification/internal gelation methods have particular advantages for encapsulation of bioactive proteins due to the mild preparation conditions and potential for scale-up. However, a limitation of conventionally-prepared calcium-crosslinked alginate microparticles is the openness of their internal structure which can result in burst drug release profiles. Thus, alginate microparticles are mainly coated with other polycationic polymers to improve their mechanical integrity in the gastrointestinal fluids. ${ }^{27,28,29,30,31}$ Moreover, other studies have found that combination of alginate and other polymers during the gelation process is a promising strategy for gastro-protective delivery of bioactive molecules. . $^{13,32,33}$ In particular, chitosan-coated alginate microspheres are effective in protecting probiotic bacteria from gastric acid and bile salts. ${ }^{34}$

In a recent study, we reported that some forms of bovine lactoferrin (bLf) are effective in substantially delaying Clostridioides difficile growth and preventing production of toxins in a human in vitro gut model of $C$. difficile infection (CDI). ${ }^{35}$ Specifically, iron-saturated, but not iron-depleted bLf at a concentration of $5 \mathrm{mg} / \mathrm{mL}$ exerted this inhibitory effect. In separate batch culture experiments, iron-saturated bLf prevented $C$. difficile vegetative cell growth and toxin production, whereas iron-depleted-bLf and iron alone did not. ${ }^{35}$ Furthermore, in comparison to iron-depleted bLf, iron- saturated bLf was observed to be more resistant to proteolytic degradation. It is well known that the therapeutic use of bLf may be limited by protein stability issues. For example, it has been reported that the absolute oral bioavailability levels of native Lf may be less than $1 \%$, limited mainly by enzymatic degradation in the gastrointestinal tract and by its poor absorption across intestinal epithelium. ${ }^{36}$ Thus, the objective of this study was to prepare and evaluate colon targeted and $\mathrm{pH}$-triggered alginate microparticles loaded with bioactive lactoferrin and to evaluate subsequently their anti- $C$. difficile defence properties in vitro. Previous work has reported a non-toxic profile for various forms of bLf irrespective of their metal saturation status. ${ }^{37}$ In this study, different forms of lactoferrin (iron-depleted; apo-bLf, iron-saturated; Fe-bLf, and manganese-saturated; Mn-bLf) were encapsulated in chitosan-coated alginate microparticles fabricated under mild conditions using the emulsification/internal gelation method. 


\section{Materials and Methods}

\subsection{Materials}

Sodium alginate (Fisher Scientific UK, catalogue number 1046-8800, general laboratory grade, molar masses not defined), bovine serum albumin-fluorescein isothiocyanate conjugate (BSA-FITC), high molecular weight chitosan $(>75 \%$ degree of deacetylation, molecular weight 310-375 kD) were obtained from Sigma-Aldrich UK. iron-saturated (85\% $\mathrm{Fe}^{3+}$ saturated) bovine holo-lactoferrin (holo-bLf), iron-depleted (1\% $\mathrm{Fe}^{3+}$ saturated) bovine apo-lactoferrin (apo-bLf), and manganese saturated bovine lactoferrin (Mn-bLf) were prepared according to the published procedure. ${ }^{37-38}$ Highly purified $C$. difficile whole toxins $A$ and B toxinotype 0, strain VPI 10463, ribotype 087, were supplied by Public Health England. All other analytical grade reagents were used without additional purification. Deionized distilled water was used to make all solutions. Calcium chloride dihydrate $\left(\mathrm{CaCl}_{2} \cdot \mathrm{H}_{2} \mathrm{O}\right)$ was purchased from Sigma-Aldrich UK and used as supplied. Dulbecco's modified eagle media (DMEM), 1\% I-glutamine (2 mM), 1\% antibiotic/antimycotic solution, 10\% fetal calf serum (FCS), and $1 \%$ non-essential amino acids were obtained from Sigma Aldrich (UK). The MTT cell metabolic activity reagent was purchased from Invitrogen. Trypan blue solution was obtained from Sigma Aldrich (UK).

\subsection{Synthesis of bLf-loaded alginate microparticles}

The emulsification/internal gelation method was used to prepare the protein-loaded alginate microparticles (Figure 1). A solution of sodium alginate (2\% w/v) was first prepared in deionized water and after this, a suspension of $5 \%(\mathrm{w} / \mathrm{v})$ of ultrafine $\mathrm{CaCO}_{3}$ was added into the alginate solution. Then, a previously prepared lactoferrin solution in deionised water $(1 \%$ $\mathrm{w} / \mathrm{v}$ ) solution was added to the above mixture and the resultant mixture was homogenised, before being dispersed into a mixture of paraffin oil and surfactant (Span 80 1\% v/v) and stirred at $1000 \mathrm{rpm}$ for 15 min using an IKA-Eurostar digital mixer with a Turbine stirrer. Following this step, a mixture of paraffin oil and glacial acetic acid $(20 \mathrm{~mL})$ was added to the above water-in-oil emulsion to reduce the $\mathrm{pH}$ of the mixture to $\sim 5$. Continuous stirring resulted in the production of microparticles, which were recovered from the oil phase by using a mixture of Tween $80(1 \% \mathrm{v} / \mathrm{v}): \mathrm{CaCl}_{2}(0.05 \mathrm{M})$, distilled water, and acetate buffer at $\mathrm{pH} 5.5$ as washing media. The microparticles were further rinsed until optical microscopy indicated that no more oil was associated with the separated particles.

\subsection{Synthesis of chitosan-coated alginate microparticles}

A chitosan solution $(0.1 \% \mathrm{w} / \mathrm{v})$ was prepared by dissolving chitosan $(0.1 \mathrm{~g}$ of a $310-375 \mathrm{kD}$ molar mass range) in $100 \mathrm{~mL}$ of acetic acid $(1 \% \mathrm{v} / \mathrm{v})$ with continuous stirring for 30 minutes. Next, the pre-prepared alginate microparticles were added to the chitosan solution. The newly formed and surface-coated microparticles were transferred into a $\mathrm{CaCl}_{2}$ solution $(0.5 \%)$ and washed with deionized water repeatedly. The resultant microparticles were stored until further use.

\subsection{Preparation of Simulated Gastric Fluid (SGF) and Simulated Intestinal Fluid (SIF)}

A solution of SGF was prepared by dissolving sodium chloride $(2 \mathrm{~g})$ in $1000 \mathrm{~mL}$ of water acidified with $\mathrm{HCl}$ to a pH of 1.2. Simulated Intestinal Fluid Test Solution was synthesised by dissolving monobasic potassium phosphate $(6.8 \mathrm{~g})$ in water $(250 \mathrm{~mL})$, then adding sodium hydroxide $(0.2 \mathrm{M}, 77 \mathrm{~mL})$ and water $(500 \mathrm{~mL})$. The $\mathrm{pH}$ of this solution was adjusted to 7.4 prior to use. 


\subsection{Determination of protein encapsulation efficiency of the microparticles}

Protein-loaded microparticles $(10 \mathrm{mg})$ were dispersed in PBS at pH of $7.4(100 \mathrm{~mL}$, containing $5 \%(\mathrm{v} / \mathrm{v})$ ethanol) and stirred continuously for $24 \mathrm{~h}$. UV-Vis spectrophotometry was used to determine the amount of free protein in supernatant via absorption at $450 \mathrm{~nm}$. The protein content and loading efficiency was calculated as described by Bosio et al $2014^{12}$ from experimentally determined calibration curves of protein content with UV absorption.

\subsection{In vitro release studies}

Simulated gastrointestinal conditions without enzyme (SGF pH 1.2 and SIF pH 7.4) were used to investigate in vitro release of encapsulated protein. Protein-loaded microparticles $(10 \mathrm{mg})$ were added to SGF $(\mathrm{pH} \mathrm{1.2,10} \mathrm{mL)} \mathrm{and} \mathrm{stirred} \mathrm{at} 100 \mathrm{rpm}$ for $2 \mathrm{~h}$. Then, the mixture was centrifuged and separated microspheres were added into SIF (pH 7.4, $10 \mathrm{~mL}$ ) and stirred for another $2 \mathrm{~h}$. Samples were taken at different time intervals from both FGF and SIF solutions to determine the protein concentration spectrophotometrically. All assays were performed in triplicate. Protein release was calculated according to the following equation.

Protein release $\%=\mathrm{Mt} / \mathrm{Mt}_{0}{ }^{*} 100$

Where Mt is the amount of protein at time $t$ and $\mathrm{Mt}_{0}$ is the amount of protein in the microparticles at time $t=0$.

\subsection{Growth of $C$. difficile in vitro and preparation of bacterial supernatants}

We used C. difficile strain 027 (PCR Ribotype 027/toxinotype III) in this study. This strain was prepared at Maine Medical Center (Portland, ME, USA) and was kindly supplied by Dr Daniela Heeg, CHAIN Biotechnology. Spores were first grown on egg yolk agar/cycloserine/cefoxitin with lysozyme (CCEY/L) for $48 \mathrm{~h}$, then transferred to a Columbia Blood agar plates. To prepare bacterial supernatants, the cultures of $C$. difficile were centrifuged at $10,000 \mathrm{~g}$ for $10 \mathrm{~min}$ and then filtered using $0.22-\mu \mathrm{m}$ filter to remove bacterial cells. Both cultures and supernatants were stored at $4^{\circ} \mathrm{C}$.

\subsection{Cultivation of Vero and Caco-2 cells on culture flasks}

Both Vero and Caco- 2 cells were maintained in DMEM culture media, in a humidified atmosphere at $37^{\circ} \mathrm{C}$ and $5 \% \mathrm{CO}_{2}$. The medium was changed every $48 \mathrm{~h}$. When the cells reached $70-80 \%$ of their confluence, they were split using trypsin to detach cells.

\subsection{Cultivation of Caco-2 cells on transwell plates}

Caco-2 cells were maintained in complete DMEM cell culture media. The media was supplemented with $2 \mathrm{mM} \mathrm{L-glutamine,} 0.1 \%$ penicillin-streptomycin solution, $10 \%$ fetal bovine serum, and $1 \%$ non-essential amino acid solution in a humidified atmosphere at $37^{\circ} \mathrm{C}$ and $5 \% \mathrm{CO}_{2}$. The cells were allowed to grow under the standard conditions until they reached $60-70 \%$ of their confluency. Cells from passages $60-80$ were used in all experiments. The cells were seeded on permeable supports (Transwell, Corning, $1.12 \mathrm{~cm}^{2}$ area, $12 \mathrm{~mm}$ diameter, and $0.4 \mu \mathrm{m}$ pore size), and the seeding density was $2 \times 10^{4} \mathrm{cells} / \mathrm{cm}^{2}$. The culture medium was added to the upper and lower compartments of the wells and the medium was changed every $48 \mathrm{~h}$. 


\subsection{Measurement of the Transepithelial Electrical Resistance (TEER)}

Barrier function integrity of the Caco-2 cell monolayers was assessed by measurement of TEER, using a portable epithelial Voltohmmeter (EVOM2, World Precision Instruments). Caco-2 cells were grown in the upper compartment of transwell inserts at $37^{\circ} \mathrm{C}, 5 \% \mathrm{CO}_{2}$. Cells were used for TEER measurements between days 14 and 21 post seeding. At the end of the growth period, plates were equilibrated at room temperature for $1 \mathrm{~h}$. TEER measurement was conducted to evaluate possible damage to cell integrity of monolayer cultured cells during the experiments. The TEER values were determined from the potential difference between the upper compartment and lower compartment, connected to a pair of 'chopstick' electrodes. The cells were washed twice with phosphate buffered saline (PBS) and pre-equilibrated for $1 \mathrm{~h}$ with Hanks' balanced salt solution (HBSS) before performing TEER measurements. Thereafter, the media was removed and $200 \mu \mathrm{L}$ of materials (toxins $A$ or B, or/and final chitosan-coated alginate microparticles loaded with $5 \mathrm{mg} / \mathrm{mL}$ of bLf) were added to the upper (apical) compartments of the transwell inserts. Subsequently, TEER measurements were conducted at $4 \mathrm{~h}, 24 \mathrm{~h}$ and $48 \mathrm{~h}$ and recorded as electrical resistance at time 0 . The electrical resistance for blank insert (no cells) and for each well was recorded.

\subsection{Trypan Blue Exclusion Assay}

Cells were incubated with trypan blue in a humidified atmosphere at $37^{\circ} \mathrm{C}$ and $5 \% \mathrm{CO}_{2}$ at a final concentration of $0.01 \%$ and visualised under light microscopy for determination of the numbers of viable (unlabeled) and damaged (blue) cells. Viability was denoted as the ratio of live cells per total cell number. After culture for $1 \mathrm{~h}$, at least 200 blue cells per well were counted to determine the proportion of damaged cells since uptake of the dye was indicative of loss of membrane integrity.

\subsection{MTT Assay}

The MTT reagent was dissolved in PBS $(\mathrm{pH}=7.4)$ to prepare a $5 \mathrm{mg} / \mathrm{mL}$ stock solution, then sterilized through a $0.2 \mu \mathrm{M}$ filter and stored at $4^{\circ} \mathrm{C}$ for frequent use, or at $-20^{\circ} \mathrm{C}$ for long term storage. 96 well plates were used to carry out cell viability measurements. The final volume of test compounds and cells was $100 \mu \mathrm{L} /$ well. The plates were incubated for $24 \mathrm{~h}$ in a humidified atmosphere at $37^{\circ} \mathrm{C}$ and $5 \% \mathrm{CO}_{2}$, after which MTT solution (10 $\mu \mathrm{L} /$ well) was added, such that the final concentration became $0.45 \mathrm{mg} / \mathrm{mL}$. Thereafter, incubation was continued for another 1 to $4 \mathrm{~h}$ at $37^{\circ} \mathrm{C}$. Finally, $100 \mu \mathrm{L}$ of solubilisation solution was added to each well and the solution absorbances were measured at $570 \mathrm{~nm}$.

\subsection{Statistical analysis}

Results are presented as mean \pm SD of three separate experiments. GraphPad Prism 7 software was used to determine the significance of differences between the values. Data were analysed by using Analysis of Variance (ANOVA) with Tukey's HSD post hoc test.

\section{Results and discussion}

\subsection{Material preparations}

Protein-loaded alginate microparticles with sizes below $100 \mu \mathrm{m}$, spherical shape and smooth morphologies were prepared using an emulsification/internal technique. Thereafter, the newly formed particles were coated with high molecular weight (>310 kDa) chitosan in order to reduce the release rate in simulated gastric conditions.. The mean diameter of uncoated microspheres was $96 \mu \mathrm{m}$ but this value increased to $113 \mu \mathrm{m}$ in the case of the chitosan 
coated microspheres. Optical microscopy observations of microparticles confirmed that their spherical shapes and smooth topologies were not affected by chitosan coating. A measure of the loading efficiency and the distribution of protein within the microparticles was obtained initially using bovine serum albumin-fluorescein isothiocyanate conjugate (BSA-FITC) as a model therapeutic protein. As apparent from Figure 2 (right-hand fluorescence microscopy images) the protein was clearly present at the surfaces of the microcapsules and in regions extending into the interior. Typical protein encapsulation efficiency of the alginate microparticles ranged from $75-85 \%$.

Release studies of bLf were conducted in SGF (pH 1.2, approximate $\mathrm{pH}$ of stomach fluid) and subsequently in SIF (pH 7.4, chosen to mimic the $\mathrm{pH}$ at the initial entry to the colon rather than in the distal colon where $\mathrm{pH}$ can be 7.8-8.5) to mimic the dynamic conditions of physiological gastrointestinal conditions (Figure 3). At pH 1.2 (SGF), a burst release profile of protein was observed during the first $30 \mathrm{~min}$ of the assay, with uncoated microparticles releasing $60-67 \%$ of encapsulated bLf protein at $\mathrm{pH} 1.2$ with residual protein gradually released at $\mathrm{pH} 7.4$ during the next $90 \mathrm{~min}$. The release of protein was also of a 'burst profile' at $\mathrm{pH} 7.4$ (SIF) during the first $30 \mathrm{~min}$, then of a slower nature throughout the next $90 \mathrm{~min}$. These initial release profiles were likely indicative of protein associated with surface layers of the microparticles rather than entrapped within the cores. The final amount of bLf released was strongly $\mathrm{pH}$-dependent (Figure 3). This we attribute to $\mathrm{pH}$-dependent differences in the electrostatic and hydrogen-bonding interactions of the alginate and chitosan-alginate matrices and bLf molecules. In SGF (pH 1.2), the bLf was well below its $\mathrm{pl}(\sim 7.9)$ and thus highly protonated. Accordingly, exposing bLf loaded alginate microparticles to acidic media resulted in neutralization of the negative charge on alginate. This effect led to substantial weakening of the electrostatic interaction between bLf and alginate that in turn resulted in greater release of encapsulated bLf from the uncoated i.e. alginate-only microspheres at $\mathrm{pH}$ 1.2 compared to the chitosan-coated microspheres. The latter microparticles were expected to remain strongly protonated at $\mathrm{pH} 1.2$, thereby retaining bLf in the chitosan-coated regions and reducing the burst release at this $\mathrm{pH}$ from the coated microspheres, as again apparent from Figure 3. Protein leaching from hydrogel beads due to reduced charge interactions has

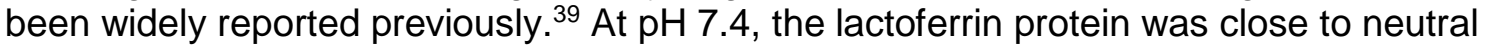
charge, while the alginate components were more negatively charged, reducing bLf-alginate charge-charge repulsion, but the additional factor of microsphere swelling from alginatealginate charge-charge repulsion enhanced the release rate of the protein at this higher $\mathrm{pH}$ value (up to $100 \%$ within $2 \mathrm{~h}$ ).

As noted above, chitosan-reinforced alginate microparticles showed delayed release of proteins at $\mathrm{pH} 1.2$ and the amount of released bLf in SGF after $2 \mathrm{~h}$ was reduced to below $40 \%$. Since chitosan was expected to be positively charged under acidic conditions, the reduced release profile may have been due to the charge effects as described above, but also a function of the hindered diffusion of bLf caused by the additional polymeric layer, which itself was partly charge-related. The release profile at $\mathrm{pH} 7.4$ was similar to that observed for uncoated alginate microparticles, with a difference seen in the starting point. The overall release of the protein at the same time points was lower for the coated microparticles as expected. (Figure 3). These results demonstrated that alginate microparticles that were reinforced with chitosan offered more sustained gastrointestinal release of protein drugs. However, the incomplete bLf release from the chitosan-coated microparticles over the assay period suggested that some of the protein was entrapped in tightly charge-cross-linked-regions of the polyelectrolyte complexes between alginate and chitosan which did not dissociate even at the higher $\mathrm{pH}$ values of the SIF medium. Recent studies indicate that this relatively slower release profile can be extended over a time span of $20 \mathrm{~h} .{ }^{40}$

\subsection{Cell culture studies}


Epithelial cell culture integrity was monitored by measuring TEER values $\left(\Omega . \mathrm{cm}^{2}\right)$ following treatment with the final chitosan-coated alginate microparticles loaded with bLf; decreasing values reflect increasing epithelial permeability resulting from membrane or tight-junction damage by the protein. The treatment of Caco-2 cells with different forms of encapsulated bLf $(5 \mathrm{mg} / \mathrm{ml})$ led to increases in TEER values as compared to treatment with toxin A (Figure 4a) or $C$. difficile strain 027 bacterial supernatant alone (Figure 5). These results suggest that bLf may have protective effects against $C$. difficile bacterial supernatant and toxinmediated intestinal mucosal damage and impairment of barrier function in intestinal epithelial cells.

The effect of toxin B was more obvious on the metabolic activity of Vero cells. Therefore, an MTT assay was used to test cellular mitochondrial dehydrogenase activity, cell growth, and survival. There was a significant increase in cell viability, as measured by the MTT cytotoxic assay, in Caco-2 monolayers exposed to the higher concentrations $(100 \mathrm{ng} / \mathrm{mL}, 1000 \mathrm{ng} / \mathrm{mL})$ of toxin A following treatment with chitosan-coated alginate microparticles loaded with lactoferrin (Figure 6a). Similar protective effects were seen with Caco-2 monolayers exposed to $C$. difficile bacterial supernatant (Figure 6b). Pre-treatment of Vero cell monolayers with all forms of encapsulated bLf followed by exposure to toxin B (Figure $4 \mathrm{~b}$ ) or $C$. difficile strain 027 bacterial supernatant for $24 \mathrm{~h}$ induced a dose-dependent fall in mitochondrial enzyme activity (Figure 6c).

Phase contrast microscopy studies demonstrated that $C$. difficile toxin A induced cell rounding in the Caco-2 cell lines. Cells within the detached monolayers initially remained adherent to each other (Figure 7). Subsequently, floating cells, smaller in size that those adherent to each other, appeared in increasing numbers with time. A similar pattern emerged for Vero cells exposed to toxin B or bacterial supernatant. Phase contrast microscopy images showed that detached Vero cells which had become detached from the culture dish seemed to be healthy while adherent to each other (Figure 8).

\section{Conclusions}

There is still limited information regarding the mode of action of lactoferrin and whether saturation of the protein with iron or manganese, or its encapsulation, effects its function. Currently, most of the in vitro digestion studies indicate that lactoferrin gets completely degraded during gastric passage and hence it cannot reach the absorption sites of the intestine. ${ }^{41}$ Therefore, encapsulation could be used to modulate the digestion behaviour of lactoferrin and hence achieve sufficient bioavailability through oral administration. The objective of this study was to prepare and evaluate colon-specific and $\mathrm{pH}$-triggered alginate microparticles to carry and protect free and metal-loaded bLf preparations against enzymatic and acidic degradation or loss of bioactivity during gastric passage, to facilitate controlled colon release of protein, and to assess subsequently their anti- $C$. difficile defence properties in vitro. In this study, different forms of lactoferrin (iron-depleted; apo-bLf, iron-saturated; holo-bLf, and manganese-saturated; Mn-bLf) were encapsulated in chitosan-coated alginate microparticles fabricated using the emulsification/internal gelation method. We tested one concentration of bLf $(5 \mathrm{mg} / \mathrm{mL})$ in line with our previous research which demonstrated that this concentration inhibited $C$. difficile growth and toxin production in a human in vitro gut model of $C$. difficile infection. ${ }^{35}$ Moreover, this same concentration was effective in significantly reducing the occurrence of antibiotic-associated diarrhoea in long-term care patients compared with placebo. ${ }^{42}$

The biological activities of the various encapsulated bLf forms that differed in their metal saturation levels were evaluated on intestinal epithelial barrier function following interaction with $C$. difficile purified toxins and bacterial supernatants. The overall results suggest that hydrogel microparticles are suitable for capsulation and $\mathrm{pH}$-triggered release of all forms of 
lactoferrin, which may be advantageous for controlled delivery of lactoferrin into the colon. Cell culture studies showed that the application of lactoferrin-loaded alginate microparticles significantly reduced the cytotoxic effects of purified whole $C$. difficile toxins $A$ and $B$ as well as bacterial supernatant on hIECs, irrespective of metal saturation status. Although our findings suggest that encapsulated bLf appears to render intestinal epithelia less susceptible to $C$. difficile toxins and bacterial supernatant, it remains to be determined if encapsulated bLf can increase expression of tight junction proteins to enhance epithelial barrier function. Whilst recent research has shown that bLf decreases paracellular permeability and increases TEER through increased expression of claudin-1, occludin, and zonula occludens1 tight junction proteins, ${ }^{43}$ others have reported no change in the production of tight junction proteins regardless of lactoferrin metal saturation. ${ }^{37}$ Moreover, it remains unclear if such effects observed in the present study can be reproduced in vivo using a murine model of CDI. Further laboratory studies will also be required to investigate the immunomodulatory, anti-inflammatory and cell-proliferative activities of encapsulated bLf at the mucosal level in animal experiments, and if the antimicrobial activity of bLf exerts it beneficial effects on the structure and function of the intestinal microbiota. Interestingly, Mn-bLf can deliver manganese ions to Lactobacillus strains, thereby enhancing their growth, although it is not known if the latter form of bLf can also effect the growth of $C$. difficile or other bacteria in the gut. Moreover, all forms of bLf (apo-, holo, and manganese-saturated) can inhibit secretion of pro-inflammatory cytokines from LPS-activated macrophages. ${ }^{37}$ In addition, microencapsulation of $L$. gasseri and $B$. bifidum with alginate and chitosan coating can significantly improve bacterial survival in simulated gastrointestinal conditions, and allow viable cells to reach beneficial levels in the colon. ${ }^{34}$

In conclusion, our results are the first to suggest that the chitosan-coated alginate microparticles loaded with bLf show protective effects against $C$. difficile bacteria and toxinmediated mucosal damage and impairment of barrier function in hIECs. This may be especially advantageous since lactoferrin would be maintained intact under gastric conditions, thus reaching the lower gastrointestinal tract where it needs to direct its therapeutic effect against this recalcitrant anaerobe and its main virulence factors.

\section{Conflicts of Interests}

There are no conflicts of interest to declare.

\section{Acknowledgements}

This research was financially supported by an EPSRC Bridging the Gaps grant awarded to TM and CA in 2016.

\section{CRediT author statement}

Shwana Braim: conceptualization, methodology, investigation, validation, formal analysis, visualization and writing original draft preparation. Klaudyna Śpiewak: investigation, resources, reviewing and editing original draft. Malgorzata Brindell: investigation, resources, reviewing and editing original draft. Daniela Heeg: resources, reviewing and editing original draft. Cameron Alexander: reviewing and editing original draft, supervision and funding acquisition. Tanya Monaghan: conceptualization, reviewing and editing original draft, supervision and funding acquisition. 


\section{Data access statement}

All raw data created during this research are openly available from the corresponding authors (cameron.alexander@nottingham.ac.uk and tanya.monaghan@nottingham.ac.uk) and at the University of Nottingham Research Data Management Repository (https://rdmc.nottingham.ac.uk/) and all analysed data supporting this study are provided as supplementary information accompanying this paper. 


\section{References}

1. Choonara BF, Choonara YE, Kumar P, Bijukumar D, du Toit LC, Pillay V. A review of advanced oral drug delivery technologies facilitating the protection and absorption of protein and peptide molecules. Biotechnol Adv 2014; 32(7): 1269-82.

2. Hwang SR, Byun Y. Advances in oral macromolecular drug delivery. Expert Opin Drug Deliv 2014;11(12):1955-67.

3. Philip AK, Philip B. Colon targeted drug delivery systems: a review on primary and novel approaches. Oman Med J 2010;25(2):79-87.

4. Van den Mooter, G, Samyn C, Kinget R. In vivo evaluation of a colon-specific drug delivery system: an absorption study of theophylline from capsules coated with azo polymers in rats. Pharm Res 1995;12 (2):244-7.

5. Chaurasia M, Chourasia MK, Jain NK, Soni V, Gupta Y, Jain SK. Methotrexate bearing calcium pectinate microspheres: a platform to achieve colon-specific drug release. Curr Drug Deliv 2008;5 (3):215-9.

6. Mundargi RC, Babu VR, Rangaswarny V, Patel P, Aminabhavi TM. Nano/micro technologies for delivering macromolecular therapeutics using poly(D,L-lactide-coglycolide) and its derivatives. J Control Release 2008;125(3):193-209.

7. Sosnik A. Alginate Particles as Platform for Drug Delivery by the Oral Route: State-ofthe-Art. ISRN Pharm 2014: 926157.

8. Liu J, Chen L, Li L, Hu X, Cai Y. Steady-state fluorescence study on release of camptothecin from agar hydrogel. Int J Pharm 2014;287(1-2):13-9.

9. Shiraishi S, Imai T, Otagiri M. Controlled-release preparation of indomethacin using calcium alginate gel. Biol Pharm Bull 1993;16(11):1164-8. 
10. Tateshita K, Sugawara S, Imai T, Otagiri M. Preparation and evaluation of a controlledrelease formulation of nifedipine using alginate gel beads. Biol Pharm Bull $1993 ; 16(4): 420-4$.

11. Kato Y, Hosokawa T, Hayakawa E, Ito K. Influence of liposomes on tryptic digestion of insulin. II. Biol Pharm Bull 1993;16(8):740-4.

12. Bosio VE, Lopez AG, Mukherjee A, Mechetti M, Castro GR. Tailoring doxorubicin sustainable release from biopolymeric smart matrix using congo red as molecular helper. J Mater Chem B 2014;2:5178-86.

13. Blandon LM, Islan GA, Casro GR, Noseda MD, Thomaz-Soccol, V, Soccol, CR. Kefiran-alginate gel microspheres for oral delivery of ciprofloxacin. Colloids Surf B Biointerfaces 2016;145:706-15.

14. Li W, Zhang L, Ge X, Xu B, Zhang W, Qu L, Choi CH, Xu J, Zhang A, Lee H, Weitz DA. Microfluidic fabrication of microparticles for biomedical applications. Chem Soc Rev 2018;47(15):5646-83.

15. Chung BG, Lee $\mathrm{KH}$, Khademhosseini $\mathrm{A}$, Lee $\mathrm{SH}$. Microfluidic fabrication of microengineered hydrogels and their application in tissue engineering. Lab Chip $2012 ; 12(1): 45-59$.

16. Kang E, Shin SJ, Lee KH, Lee SH. Novel PDMS cylindrical channels that generate coaxial flow, and application to fabrication of microfibers and particles. Lab Chip 2010;10(14):1856-61.

17. Liu H, Li G, Sun X, He Y, Sun S, Ma H. Microfluidic generation of uniform quantum dot-encoded microparticles by gelation of alginate. RSC Adv 2015;5(77):62706-12. 
18. Fundueanu G, Nastruzzi C, Carpov A, Desbrieres J, Rinaudo M. Physico-chemical characterization of Ca-alginate microparticles produced with different methods. Biomaterials 1999;20(15):1427-35.

19. Cui JH, Goh JS, Park SY, Kim PH, Le BJ. Preparation and physical characterization of alginate microparticles using air atomization method. Drug Dev Ind Pharm $2001 ; 27(4): 309-19$.

20. Cascone, S, Lamberti G, Titomanlio G, Barba AA, d'Amore M. Microencapsulation effectiveness of small active molecules in biopolymer by ultrasonic atomization technique. Drug Dev Ind Pharm 2012; 38(12):1486-93.

21. Reis CP, Neufeld RJ, Vilela S, Ribeiro AJ, Veiga F. Review and current status of emulsion/dispersion technology using an internal gelation process for the design of alginate particles. J Microencapsul 2006;23(3):245-57.

22. Builders PF, Kunle OO, Okpaku LC, Builders MI, Attama AA, Adikwu MU. Preparation and evaluation of mucinated sodium alginate microparticles for oral delivery of insulin. Eur J Pharm Biopharm 2008;70(3):777-83.

23. Crcarevska MS, Dodov MG, Goracinova K. Chitosan coated Ca-alginate microparticles loaded with budesonide for delivery to the inflamed colonic mucosa. Eur J Pharm Biopharm 2008;68:565-78.

24. Hariyadi DM, Wang Y, Lin SC, Bostrom T, Bhandari B, Coombes AG. Novel alginate gel microspheres produced by impinging aerosols for oral delivery of proteins. $\mathrm{J}$ Microencapsul 2012;29(3):250-61.

25. Hariyadi DM, Bostrom T, Bhandari B, Coombes AG. A novel impinging aerosols method for production of propranolol hydrochloride-loaded alginate gel microspheres for oral delivery. J Microencapsul 2012;29(1):63-71. 
26. Iwanaga S, Saito N, Sanae H, Nakamura M. Facile fabrication of uniform sizecontrolled microparticles and potentiality for tandem drug delivery system of micro/nanoparticles. Colloids Surf B Biointerfaces 2013;109:301-6.

27. Matricardi P, Meo CD, Coviello T, Alhaique, F. Recent advances and perspectives on coated alginate microspheres for modified drug delivery. Expert Opin Drug Deliv $2008 ; 5(4): 417-25$.

28. Zarate J, Virdis L, Orive G, Igartua M, Hernandez RM, Pedraz, JL. Design and characterization of calcium alginate microparticles coated with polycations as protein delivery system. J Microencapsul 2011;28(7):614-20.

29. Urbanska AM, Karagiannis ED, Guajardo G, Langer RS, Anderson DG. Therapeutic effect of orally administered microencapsulated oxaliplatin for colorectal cancer. Biomaterials 2012;33(18):4752-61.

30. Gattás-Asfura KM, Valdes M, Celik E, Stabler CL. Covalent layer-by-layer assembly of hyperbranched polymers on alginate microcapsules to impart stability and permselectivity. J Mater Chem B 2014;2(46):8208-19.

31. Liu Y, Chen Z, Wang S, Long R, Fan J, Chen A, Wu W. Preparation of ALG-g-Lys and its application as a novel drug carrier. J Mater Chem B 2015;3(17):3420-24.

32. Islan GA, de Verti IP, Marchetti SG, Castro GR. Studies of ciprofloxacin encapsulation on alginate/pectin matrixes and its relationship with biodisponibility. Appl Biochem Biotechnol 2012;167(5):1408-20.

33. Boppana R, Kulkarni RV, Mohan GK, Mutalik S, Aminabhavi TM. In vitro and in vivo assessment of novel $\mathrm{pH}$-sensitive interpenetrating polymer networks of a graft copolymer for gastro-protective delivery of ketoprofen. RSC Adv 2016; 6 (69):6434456. 
34. Chavarri M, Maranon I, Ares R, Ibanez FC, Marzo F, del Cermen Villaran M. Microencapsulation of a probiotic and prebiotic in alginate-chistosan capsules imprives survival in simulated gastro-intesintal conditions. Int J Food Microbiol 2010; 142 (1-2): 185-9.

35. Chilton $\mathrm{CH}$, Crowther GS, Spiewak K, Brindell M, Singh, G, Wilcox MH, Monaghan, TM. Potential of lactoferrin to prevent antibiotic-induced Clostridium difficile infection. J Antimicrob Chemother 2016;71(4):975-85.

36. Yao X, Bunt C, Cornish J, Quek SW, Wen J. Oral Delivery of Lactoferrin : A Review. Int J Pept Res Ther 2013; 19 (2): 125-134.

37. Majka G, Wiecek G, Srottek M, Spiewak K, Brindell M, Koziel J, Marcinkiweicz, J, Strus M. The impact of lactoferrin with different levels of metal saturation on the intestinal epithelial barrier function and mucosal inflammation. Biometals 2016;29(6):1019-33.

38. Spiewak K, Majka G, Pilarczyk M, Nowak PM, Woznikiewicz M, Pietrzyk P, Korzeniak T, Stochel-Gaudyn A, Fyderek K, Strus M, Brindell M. $\mathrm{Mn}^{3+-}$ saturated bovine lacotferrin as a new complex with potential prebiotic activities for dysbiosis treatment and prevention - On the synthesis, chemical characterization and origin of biological activity. J Funct Foods 2017; 38; 264-272.

39. Zhang Z, Zhang R, Zou L, McClements DJ. Protein encapsulation in alginate hydrogel beads: Effect of $\mathrm{pH}$ on microgel stability, protein retention and protein release. Food Hydrocoll 2016; 58: 308-315.

40. Silva CM, Ribeiro AJ, Figueiredo M, Ferreira M, Veiga F. Microencapsulation of Hemoglobin in Chitosan-coated Alginate Microspheres Prepared by Emulsification/Internal Gelation. AAPS J 2006; 7 (4): 903-913. 
41. Wang B, Timilsena YP, Blanch E, Adhikari B. Lactoferrin: Structure, function, denaturation and digestion. Crit Rev Food Sci Nutr 2017; 1-17. Doi:10.1080/10408398.2017.1381583.

42. Laffan AM, McKenzie R, Forti J, Conklin D, Marcinko R, Shrestha R, Bellantoni M, Greenough III WB. Lactoferrin for the prevention of post-antibiotic diarrhoea. J Health Popul Nutr 2011; 29: 547-51.

43. Zhao X, Xu XX, Liu Y, An JJ, Tabys D, Liu N. The In Vitro Protective role of Bovine Lactoferrin on Intestinal Epithelial Barrier. Molecules 2019; doi: 10.3390/molecules24010148. 


\section{Figure Legends}

\section{Figure 1}

Schematic shows lactoferrin encapsulation in alginate-based microparticles and release in gastric and colonic fluid

\section{Figure 2}

Optical and fluorescent microscopy images of protein-loaded alginate microparticles before and after coating with chitosan. Scale bars are $100 \mu \mathrm{m}$.

\section{Figure 1}

In vitro release profile of different forms of lactoferrin in simulated gastric fluid (SGF) and in simulated intestinal fluid (SIF) for uncoated (blue line) and chitosan-coated (red line) alginate microparticles. Results are shown as the means \pm standard deviations derived from three independent experiments.

\section{Figure 2}

A. The effects of $C$. difficile toxin A on transepithelial electrical resistance (TEER) of cultured Caco-2 enterocytes at $48 \mathrm{~h}$ after treatment are reduced by exposure to bovine lactoferrin. The TEER is presented as percent change from baseline. Values represent mean \pm SE of at least 3 tissue culture wells derived from 3 independent experiments. B. Vero cell cytotoxicity assay. Vero cells after treatment with bLf and then subjected to different concentrations of toxin B, as measured by the MTT cytotoxic assay. Results are shown as the means \pm standard deviations derived from three independent experiments. ${ }^{* * *}=\mathrm{p}<0.0001 ;{ }^{* * *}=$ $p<0.001 ;{ }^{* *}=p<0.01 ;{ }^{*}=p<0.05$.

\section{Figure 5}

A. TEER\% vs. time profiles observed for Caco-2 cell monolayers. B. Effects of different forms of metal bound and encapsulated bovine lactoferrin on the TEER (\% relative to initial value) of polarized Caco-2 cell monolayers in the presence or absence of bacterial supernatant samples of the epidemic $027 \mathrm{C}$. difficile strain at $48 \mathrm{~h}$. Values represent mean \pm SE of at least 3 tissue culture wells derived from 3 independent experiments. ${ }^{\star \star \star \star}=$ $p<0.0001$ 


\section{Figure 6}

Cell viability in Caco-2 monolayers incubated with different form of metal bound and encapsulated bovine lactoferrin and then exposed to A. C. difficile toxin A B. bacterial supernatant of epidemic $027 \mathrm{C}$. difficile strain. After culture for $24 \mathrm{~h}$, the percentage of trypan blue unstained/viable cells was determined. C. Vero cell cytotoxicity assay. Vero cells after treatment with metal bound and alginate encapsulated bovine lactoferrin (Lf-alginate beads) and then subjected to bacterial supernatant of epidemic $027 \mathrm{C}$. difficile strain, as measured by the MTT cytotoxic assay. Results are shown as the means \pm standard deviations derived from three independent experiments. ${ }^{* * *}=p<0.0001$

\section{Figure 7}

Phase contrast photomicrograph of Caco-2 monolayer cells exposed to $C$. difficile toxin A and bacterial supernatant from 027 C. difficile strain. Toxin-exposed monolayer shows cell rounding and focal loss of cell-cell contacts. A significant proportion of the monolayer has also become detached from the bottom of the culture plate.

\section{Figure 8}

Phase contrast photomicrograph of Vero monolayer cells exposed to $C$. difficile toxin $B$ and bacteria supernatant strain 027 201, PCR ribotype 027. Toxin-exposed monolayer shows cell rounding and focal loss of cell-cell contacts. Not evident from the Figure is the fact that a significant proportion of the monolayer has also become detached from the bottom of the culture plate by this time. 